\title{
Erratum to: Race, Isolation, and Exclusion: What Early Childhood Teacher Educators Need to Know About the Experiences of Pre-service Teachers of Color
}

\section{Ranita Cheruvu • Mariana Souto-Manning • Tara Lencl • Marisa Chin-Calubaquib}

\section{Erratum to: Urban Rev \\ DOI 10.1007/s11256-014-0291-8}

Please note that Teachers College, Columbia, is the sole affiliation for co-authors Mariana Souto-Manning and Marisa Chin-Calubaquib.

University of Georgia is not a valid affiliation for Mariana Souto-Manning and University of San Diego is not a valid affiliation for Marisa Chin-Calubaquib. These affiliations were provided on error.

The online version of the original article can be found under doi:10.1007/s11256-014-0291-8.

R. Cheruvu - M. Souto-Manning · T. Lencl · M. Chin-Calubaquib

Teachers College, Columbia University, New York, NY, USA

R. Cheruvu $(\bowtie)$

William Paterson University, Department of Elementary and Early Childhood Education,

300 Pompton Road, Wayne, NJ 07470, USA

e-mail: CheruvuR@wpunj.edu 